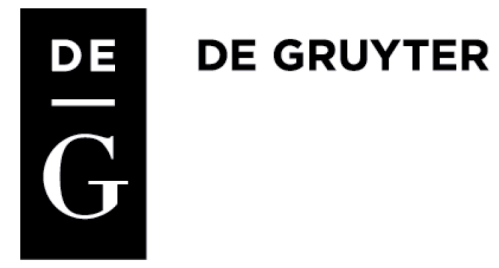

\title{
SCOUTMASTER JAN POPLEWSKI - AN EXAMPLE OF ATTRIBUTING FINANCIAL CRIME TO OPPONENTS OF THE COMMUNIST REGIME
}

The article describes a failed attempt to attribute financial crime - embezzlement of the money belonging to the Greater Poland Headquarters of the Local Council of the Polish Scouting and Guiding Association - to scoutmaster Jan Poplewski. However, from the very beginning, the security services were interested in his anti-systemic activity, i.e. inspiring illegal activities among young scouts in the Stalinist period. This story serves as an example for exploring the underresearched problem of attributing various crimes to the opponents of the system, in order to discredit them and use this fact for propaganda purposes. The scale of this problem is impossible to estimate at present, but sometimes it is possible to describe individual cases - for example the case of scoutmaster Jan Poplewski.

Keywords: scouting, Jan Poplewski, scouting conspiracy, financial crime, embezzlement. doi:10.1515/sho-2016-0011

\section{INTRODUCTION}

In the Polish People's Republic, opponents of the system were in some cases accused of committing financial crimes [Zaćmiński A. 2008: 23-28] so as to ruin their reputation for propaganda purposes. Unfortunately, at present it is beyond our means to estimate the scale of the problem [Zaćmiński A. 2008: 23-28], but we can sometimes describe individual examples. One such example is the case of Jan Poplewski and the attempts to charge him with a common crime, although it was clear from the very beginning that his main crime was his anti-system activity. These plans were not accomplished, as in the end it was possible to charge him explicitly with inspiring illegal activity among the youth, but what is important here is the mechanism itself. 


\section{SCOUTMASTER JAN POPLEWSKI - A PROFILE}

Poplewski was born on June 20, 1896 in Poznań. Due to his family situation, he had to grow up fast and start making a living. While still in school, he sold newspapers, worked as an errand boy, helped out in a hotel in Gniezno, and even was a painter's helper. At the same time, in 1912, he joined the scout movement developing in the Prussian partition territory. As it turned out, this was a life-long commitment. Joining scouts equaled joining the independence movement - he was a member of the $2^{\text {nd }}$ platoon of the "Piast" squad in Chwaliszewo under the command of Wincent Wierzejewski, a co-founder of the Polish Military Organization in the Prussian Partition. Henryk Śniegocki and Józef Dunst (later involved in the independence conspiracy) were among his superiors and friends in the scout movement. In October 1915, he was conscripted into the Prussian Grenadiers Regiment no. 6 in Wschowa. Although his health was in fact weak, he also faked symptoms so that his condition would seem more serious. This helped him avoid being sent to the front, and after two months he was referred to work in garrison services in Poznan [IPN Po (Institute of National Remembrance Poznań) 04/1479, f. 147].

Once back in his home town, Poplewski immediately joined the POW ZP organization, acquiring weaponry and other army equipment for conspirators. This activity almost resulted in his arrest [Rzepecki K. 1919: no page number.; Pietrzykowski M. 1999: 10; Nowicki T. 1996: 4]. During the Greater Poland Uprising he took part e.g. in capturing the airport in Ławica. However, his poor health manifested itself once again - a serious lung disease kept him from combat for several weeks. After recovery, he served in the People's Guards, and after the uprising, he found his way to the Garrison Battalion, with which he went to fight the Bolsheviks in the East. By that time, he had already been promoted to the rank of corporal and awarded the Cross of Valor. During the Polish-Soviet war he was promoted to platoon leader. After the war, Poplewski remained in the army, promoted to sergeant and working as a clerk in the $7^{\text {th }}$ Corps District Headquarters in Poznań. In 1925, he fell gravely ill - he spent six months in hospital, and some more time in recovery. After two years, he retired from the army. However, the army retirement did not put a halt to his activity in the scout movement. From 1923 on, while still in the army, he volunteered in the Scouts' Greater Poland Local Council, therefore, when he had to leave the army, he was offered employment in the The Polish Scouting and Guiding 
Association (ZHP). Until 1939 his work involved inspecting scouting teams outside of Poznan, which meant that he was one of the most well-known instructors of the Headquarters in the field [IPN Po 04/1479, f. 147].

During the Second World War, he was drafted into the military censorship service, and with his unit he made it to Równe. After defeat in the campaign, he returned to Poznań. Here, he was warned that he was wanted by the Germans, because he of his participation in the Greater Poland Uprising and because he was a scouting instructor. His flat was sealed off and there was a summons from the occupational authorities waiting for him. At first, in order to avoid arrest, he remained in hiding in Poznan, however after a couple of weeks, he decided to escape to the General Governorate. In the end, he decided to stay with his uncle who had been evicted by the Germans and lived in Ostrowiec Świętokrzyski [IPN Po 04/1479, f. 147]. In the Świętokrzyskie region, Poplewski joined the Home Army (very active in this region) and was as a part of a combat and subversion group in Ostrowiec [Nowicki T. 1996: 7]. At that time, he started contacting scouts whom he knew from his pre-war inspections, which convinced him that it was necessary to include scouts in the post-war economic reconstruction and aid for the victims of the war. This was to be done by establishing cooperatives manufacturing small everyday-use items and, of course, elements of scout uniforms. According to Poplewski, the optimum number of members in each cooperative was ten people. Hence their name - the "economic tens". Apart from their economic activities, the "tens" were also supposed to prepare young people for work, and a part of their profit was to be spent on helping the poor [IPN Po 05/280, f. 15]. The scoutmaster spent the whole period of occupation in Ostrowiec. However, once Germans had been forced out of Poznan, he came back to the city and immediately reported for scouting service in the Local Council Headquarters, where he was once again employed as an inspector [IPN Po 04/1479, f. 148a].

\section{ACCUSATIONS OF FINANCIAL CRIME AND ANTI-GOVERNMENT ACTIVITY}

Poplewski started to implement his idea of "economic tens" by creating the "Bukowianka" work cooperative in a small town of Buk, and the "KA-DE-HA" Scouting Deliveries Committee [IPN Po 05/280, f. 16; Nowicki T. 1996: 8-9; Fludra Z. 2000: 37]. However, these ideas were in 
contrast with the plans of scouting authorities, as the scouts from cooperatives were also expected to nurture the traditions of pre-war scouting movement. Poplewski could not accept the fact that the communists had more and more control over the Scouting Association. During his inspections in the field, he talked to people he trusted about maintaining traditional values in the squads, especially since the authorities openly worked to abolish scouting in its traditional form [IPN Po 05/280, f. 15].

From the very beginning of communism in Poland, scouting and scouting camps in particular [Kuświk B. 2011] were under strict "operational surveillance", which intensified even more along with the preparations to assume full control over the ZHP by the Union of Polish Youth. At first, the officers became interested in the KA-DE-HA cooperative. Information was collected as to where the manufacturing materials came from, what happened to the funds, and what the remunerations of the employees were. According to the scarce information found in archive documents [IPN Po 003/428, ff 1-27], this material was to be used as evidence against people engaged in the activity of the "economic tens" - as it turned out, a few members of the cooperatives were involved in independence conspiracy [IPN Po 04/1479, f. 145]. For unknown reasons, this angle was not investigated further, but the fact remains that in 1950, there were two separate cases against Jan Poplewski.

The first one seems to be a provocation against the scoutmaster. On March 30, 1950, Poplewski was detained and interrogated as a suspect in the Citizen's Militia Station no. 1 in Poznań. He was accused of embezzling a large amount of money intended for the salaries of ZHP employees. The account of Karol Kalkowski, who was responsible at that time for all financial matters of the Local Council Headquarters ${ }^{1}$, and the interrogation report on Poplewski (kept in the files as an unsigned typescript) [IPN Po 04/1479, ff 65-67] tell two different stories. According to the report, Poplewski fell victim of a common extortion, while according to Kalkowski, there was an attack in which Poplewski was beaten up. Eventually, the case was closed by the Security Office officer who stated that the materials:

[...] are too weak to send Poplewski individually to trial, and therefore there is a concern that Poplewski would get a small, maybe even suspended, sentence. However, if Poplewski stands in the dock with the other members of the illegal "Bi-Pi" organi-

1 The account of Karol Kalkowski given in person to the author on March 6, 2009. Typescript in the author's possession. 
zation (the creation of which he inspired), I am most certain that the sentences will be heavier [IPN Po 04/1479, f. 144].

That is how it the officers decided not to try to have the scoutmaster convicted for embezzling the associations' money after all, but to simply "add" him to one of the illegal scouting organizations which operated at the time. The opportunity appeared in spring of 1950, when anti-communist slogans appeared on walls in Buk. There were also leaflets, the content of which clearly indicated that the authors were scouts, as some called for boycotting "the new scouting movement". According to the procedure in force at the time [The instruction on acquisition, performance and registration... 2004: 23], the investigators selected the people who could know more about the perpetrators or who had valuable contacts, and recruited them as collaborators. The officers were very lucky, as they found Bogdan Banaszkiewicz, a scout from Buk, and arrested him in secret on March 23, 1950. All they expected to learn was something about the scouting environment in Buk, but they were lucky enough to find a terrified teenager who, to the investigators' surprise, claimed that he was the head of the "Bi-Pi" organization ${ }^{2}$ which distributed leaflets. That same night of March 23, 1950, they arrested other members of the organization. Apart from Bogdan Banaszkiewicz, these were: Florian Dorszyk, Maria Lulkiewicz, Marian Połka, Maria Szajek, and Henryk Sibilski [IPN Po 05/280, f. 21].

At first, the statements revolved around the scouting activity of the suspects, however, it quickly turned out that they were in contact with Jan Poplewski. It was no longer necessary to try to charge the scoutmaster with common crimes, as he could be charged with inspiring illegal activities and demoralizing the youth. It was proved that Banaszkiewicz met Poplewski several months earlier in the Buk railway station. Poplewski told him to cultivate the ideals and traditions of the old scouting movement, and to promote them among young people. This conversation was used to link Poplewski with the illegal organization [IPN Po 75/3086, ff 52-53]. At first Poplewski admitted that they had met, but denied inspiring any illegal activities [IPN Po 75/3086, f. 109]. During the investigation, the scoutmaster was beaten and humiliated [Fludra Z. 2000: 79], and his family was harassed and kept under surveillance [Fludra Z. 2000: 46]. All this concluded in a trial, in which prison sentences were administered for

2 The name originates from the initials of the scouting movement founder, Robert Baden-Powell, known under this nickname all around the world until today. 
all the suspects. On August 4, 1950, the Military District Court in Poznań in an off-site session in Buk sentenced Poplewski to 6 years in prison; other defendants received sentences between three and six years [IPN Po 75/3086, ff 228-230]. The scoutmaster did not endure the brutal investigation and died in a prison hospital on December 6 [Fludra Z. 2000: 79]. A modest funeral was held on Saturday, December 9. Although it was a regular business day (permission to hold the funeral on Sunday was denied, just in case) many people bravely decided to accompany scoutmaster Poplewski in his final journey [IPN Po 04/1479, f.197].

\section{CONCLUSION}

Only after 40 years from these events did the Silesian Military District Court in Wrocław declare the sentences against Poplewski and other convicts null and void, pointing to the fact that they worked for the independence of the Polish state [IPN Po 04/1473 vol. 2, f. 70]. Interestingly, though the scoutmaster's story is still alive, as he is remembered as a patriot, a great instructor and teacher, and one scouting squad in Buk even adopted his name, still, despite the efforts of Maria Andrysiak (née Szajek), the last living scout who was sentenced in the same trial, and the efforts of Poplewski's family, in conversations with people who knew him there was always a mention that he was involved in some case having to do with "missing money". ${ }^{3}$

It is worth noting that Jan Poplewski was not the only one to lose his life as a result of involvement in the independence movement. After serving his sentence, Florian Dorszyk, convicted in the same trial, was drafted and, as an enemy of the state, served in the mining battalion in one of the mines in Bytom [IPN Po 04/1473 vol. 1-2]. He had an accident there, but after recovery, he was once again sent to work underground. He decided to escape with Eugeniusz Melcer who, just like Dorszyk, had already served his sentence, but was still paying for his involvement in youth conspiracy. During the chase after the "AWOLs" on November 12, 1954, they both died in unexplained circumstances. Officially, they both committed

${ }^{3}$ Compare: The account of Józef Derda, Poznań, September 16, 2010; the account of Henryk Golimowski, Poznań, September 9, 2010; the account of Karol Kalkowski, Poznań, March 6, 2009. 
suicide [the account of Maria Andrysiak; IPN Po 04/1473 vol. 2, ff 7071]. However, documents mention "eliminating the bandits" and "shooting down criminals", and one document provides a version according to which Melcer committed suicide, and Dorszyk was shot during the struggle [IPN Po 04/1473 vol. 2, f. 70].

\section{APPENDIX}

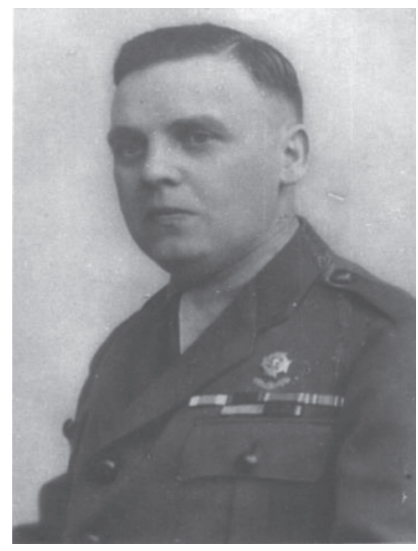

Scoutmaster Jan Poplewski

Members of the "Bi-Pi" illegal scouting team

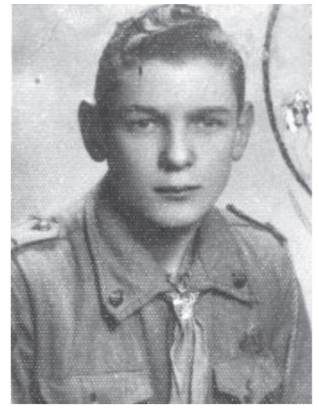

Bogdan

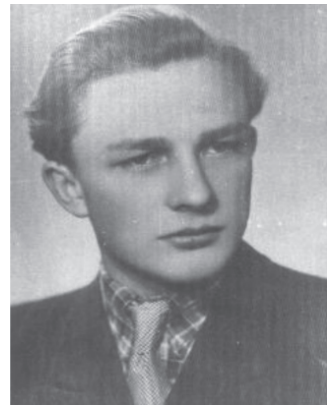

Florian Dorszyk

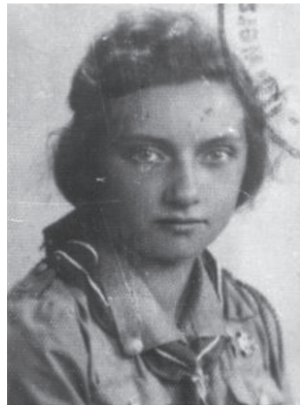

Maria Szajek

Banaszkiewicz 


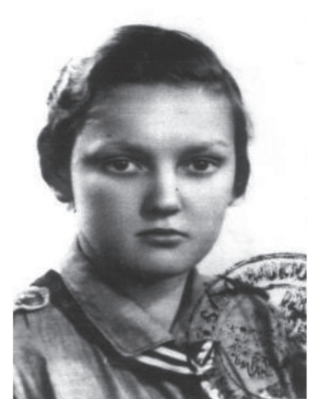

Maria Hanna

Lulkiewicz

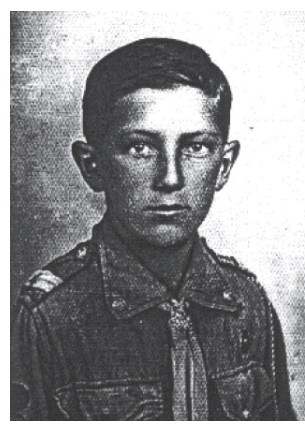

Henryk Sibilski

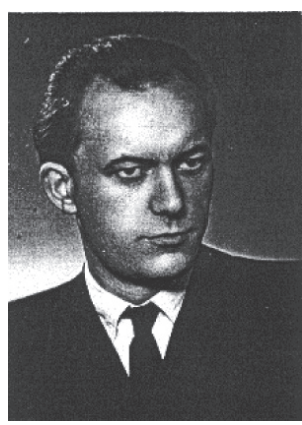

Marian Połka

Source of photos: Blimel Helena, Blimel Henryk, Powojenna Konspiracja Harcerstwa Polskiego. 1945 - -1956, cz I., wiazka IX - Konspiracyjny zastęp harcerski "Bi - Pi” w Buku. [Post-war Polish Scouting conspiracy 1945-1956, part 1, beam 9 - conspiracy scouting team 'Bi-Pi" in Buk]. The archive of the Greater Poland ZHP Local Council Historical Commission, no place, no date, no signature.

\section{BIBLIOGRAPHY:}

\section{ARCHIVE MATERIALS}

The Archive of the Institute of National remembrance in Poznan (AIPN Poznań)

AIPN Poznań, Criminal case files of Jan Poplewski and others, Military District Court (WSR) Poznań, sign. Sr 389/50, file sign. IPN Po 75/3086.

AIPN Poznań, Investigative case files sign. 9070/III of Jan Poplewski and others, file sign. IPN Po 04/1479.

AIPN Poznań, report no. 132, "C" bureau of Regional Headquarters of Citizens' Militia (KWMO) in Poznań, the "Bi-Pi" illegal youth organization. Buk, Nowy Tomyśl county, report of retired captain of Citizens' Militia K. Nowacki, 1977, file sign: IPN Po 05/280.

AIPN Poznań, Object investigation, The Polish Scouting and Guiding Association, Regional Security Office (WUBP) in Poznań, sign. 435/IV, files sign. IPN Po 003/428.

AIPN Poznań, Investigative files of Dorszyk Florian, Melcer Eugeniusz, file sign. IPN Po 04/1473, vol. 1-2.

\section{LITERATURE}

Fludra Z. (2000), Harcmistrz Jan Poplewski w życiu prywatnym [Scoutmaster Jan Poplewski in private life], Poznań.

Instrukcja (tymczasowa) [o] pozyskaniu, pracy i ewidencji agenturalno-informacyjnej sieci $z d n$. 13 lutego $1945 r$. [Temporary instruction on acquisition, performance and registration of a network of informants and agents of February 13, 1945] [in:] Rudzikowski T. (2004) “Instrukcje operacyjne aparatu bezpieczeństwa (1945-1989): Materiały pomocnicze Biura Edukacji Publicznej IPN" [Operational instructions of the security services 
1945-1989: Supplementary materials of the Public Education Bureau of the Institute of National Remembrance"], Warsaw.

Kuświk B. (2011), "Obozy pod specjalnym nadzorem...". Ochrona operacyjna obozów harcerskich na przykładzie województwa poznańskiego w latach 1946-1949 [Camps under surveillance. Operational surveillance of scouting camps based on Poznan region in the years 1946-1949] [in:] Kościk E. "Społeczny wymiar turystyki" [Social dimension of tourism], Wrocław.

Nowicki T. (1996), Znałem śp. Druha harcmistrza Jana Poplewskiego [I knew scoutmaster Jan Poplewski], Poznań.

Pietrzykowski M. (1999), Wspomnienia o śp. Druhu harcmistrzu Janie Poplewskim "Jasiu" (z lat 1945-1950) [Memories of scoutmaster Jan Poplewski - "Jaś" (from the years 19451950)], Poznań.

Rzepecki K. (1919), Powstanie grudniowe w Wielkopolsce 27. 12. 1918 [December uprising in Greater Poland, 27.12.1918], Poznań.

Zaćmiński A. (2008), Przestępstwa polityczne w orzecznictwie Komisji Specjalnej do Walki z Nadużyciami i Szkodnictwem Gospodarczym 1950-1954 [Political crimes in the jurisdiction of the Special Commission on Fighting with Fraud and Economic Abuse], "Pamięć i Sprawiedliwość", 1(12), p. 321-343.

\section{INTERVIEWS AND ACCOUNTS GIVEN TO THE AUTHOR}

The account of Józef Derda given in Poznań on September 16, 2010.

The account of Henryk Golimowski given in Poznań, September 9, 2010.

The account of Maria Andrysiak given in Poznań, March 27, 2006.

The account of Karol Kalkowski given in Poznań, March 6, 2009.

\section{PHOTOGRAPHIES}

Blimel Helena, Blimel Henryk, Powojenna Konspiracja Harcerstwa Polskiego. 1945- 1956, cz. I., wiąka IX - Konspiracyjny zastęp harcerski „Bi-Pi” w Buku. [Post-war Polish scouting conspiracy 1945-1956, part 1, beam 9 - conspiracy scouting team 'Bi-Pi" in Buk]. The archive of the Greater Poland ZHP Local Council Historical Commission.

Bartosz Kuświk - Ph.D graduated from Adam Mickiewicz University (Faculty of History), and obtained his Ph.D in history there in 2012. Since 2001, he has been working for the Institute of National Remembrance. At present, he is the Head of the Opole Branch of the Institute of National Remembrance. His research interests involve the Stalinist period and the history of scout movements. 
